2021 • Summer - Yaz • Volume - Cilt: 12 • Issue - Sayı: 46

\title{
Türkiye'deki Lisans Öğrencilerinin ve Mezunlarının Dijital Okuryazarlık Düzeylerinin İncelenmesi *
}

Serkan BAYRAKCI, Marmara Üniversitesi, İletişim Fakültesi, Gazetecilik Bölümü, Arş. Gör. Dr., serkan.bayrakci@marmara.edu.tr, (D) 0000-0002-3817-1927

Haldun NARMANLIOĞLU, Marmara Üniversitesi, İletişim Fakültesi, Gazetecilik Bölümü, Doç.Dr., hnarmanli@hotmail.com, (DD 0000-0001-5137-8407

$\ddot{O Z Z}$

Bu çalışmanın amacı Türkiye'deki üniversite öğrencilerinin ve mezunlarının dijital okuryazarlık düzeylerini ölçmektir. Bu araştırmada nicel araştırma yöntemlerinden tarama modeli uygulanmıştır. Basit tesadüfi (rastgele) örnekleme yöntemiyle çevrim içi ortamda Dijital Okuryazarlık Ölçeği (DOYÖ) 1287 katılımcıya uygulanmıştır. Araştırma kapsamında üniversite öğrencileri ve mezunlarının dijital okuryazarlık puanları katılımclların cinsiyetlerine, eğitim durumlarına, yaş gruplarına, ekonomik durumlarına, akıll cihaz kullanmaya başlama dönemine ve dijital teknolojilerle ilgili gelişmeleri takip etme biçimlerine göre farklılık gösterip göstermedikleri incelenmiştir. Ayrıca bahsi geçen değişkenlerin bazılarıla DOY puanları arasında anlaml ilişki olup olmadığı incelenmiştir. Veriler Levene varyans homojenliği, bağımsız örneklem t-testi, tek yönlü varyans analizi, Brown-Forsythe testi, Pearson ilişki testi ve Cohen's d etki büyüklüğü ve Post Hoc testi gibi çeşitli istatistiksel testler kullanılarak analiz edilmiştir. Bu araştırmada, erkek katılımcıların kadınlardan; lisans mezunlarının lisans öğrencilerden; 25-32 yaş arasındaki katılımcıların diğer yaşlardaki katılımcılardan; akıllı cihaz kullanmaya ilkokul ve öncesinde başlayanlarm üniversite ve sonrasinda başlayanlardan; teknolojik gelişmeleri takip edenlerin etmeyenlerden daha yüksek dijital okuryazarlk puanına sahip olduğu sonucuna varılmıştır.

Anahtar : Dijital Okuryazarlık, Dijital Yetkinlik, Dijital Okuryazarlık Düzeyi, Yeni Medya, Keliemeler Enformasyon Teknolojileri

* Çalışma, Marmara Üniversitesi Sosyal Bilimler Enstitüsü Bilişim Anabilim Dalı'nda, "Haldun Narmanlıŏlu" danışmanlığında yürütülen "Dijital Yetkinlikler Bütünü Olarak Dijital Okuryazarlık: Ölçek Geliştirme Çalışması" başlıklı doktora tezinden üretilmiştir. Tezin araştırma bölümü 2019 yılında tamamlanmıştır. 


\title{
Investigation of Digital Literacy Levels of Undergraduate Students and Graduates in Turkey
}

\begin{abstract}
The purpose of this study is to measure the digital literacy levels of undergraduate students and graduates in Turkey. As a research design, survey method is used. In this study, the Digital Literacy Scale (DLS) was applied online to 1287 participants by using a simple random sampling method. Within the scope of the research, it was examined whether the digital literacy scores of the university students and graduates differ according to the participants' gender, education status, age groups, economic status, the period of starting to use smart devices and the way they follow the developments related to digital technologies. In addition, it was examined whether there is a significant relationship between some of the variables mentioned and the digital literacy scores. The data were analyzed using various statistical tests such as Levene variance homogeneity, independent sample t-test, one-way analysis of variance, Brown-Forsythe test, Pearson correlation test, Cohen's d effect size and Post Hoc test. As a result of the research, male participants are more than women; undergraduate graduates than undergraduate students; participants between the ages of 25-32 than in other age groups; those who started using smart devices in primary school than those who started using at university and later; has a higher digital literacy score.
\end{abstract}

Keywords : : Digital Literacy, Digital Competence, Digital Literacy Level, New Media, Information Technologies

\section{EXTENDED ABSTRACT}

Expressing digital literacy, which affects almost all areas of life especially in economic, cultural, social and personal areas, by teachable and measurable building blocks is important in practices and future plans. There is a need for tools that can measure digital literacy. Therefore, researchers, legislators and international institutions are working on measuring digital literacy. In Turkey, as in the world, the importance given to digital literacy is increasing with both the public, academia and sector dimensions, and various studies are carried out to measure the digital literacy of students and citizens.

According to Bayrakcı and Narmanlıoğlu (2021) digital literacy is;

- To be able to use digital technologies in a suitable, safe and effective manner in many areas from learning to problem solving, entertainment to communication, citizenship practices to private space.

- To be able to produce and collaborate with digital technologies.

- To be able to evaluate digital technologies and process.

- To have awareness and critical perspective towards digital technologies. 
It includes all of the cognitive, social and technical competencies related to digital technologies.

In this study, it was aimed to measure the digital literacy levels of university students and graduates. The Digital Literacy Scale developed by Bayrakcı and Narmanlıoğlu (2021) within the scope of his doctoral thesis was used. The following questions were attempted to be answered within the scope of the research:

What are the digital literacy levels of university students and graduates? Is there a statistically significant difference in the digital literacy scores of the participants in terms of the "Gender" variable? Do the digital literacy scores of the participants show a statistically significant difference according to the "Education Level" variable? Do the digital literacy scores of the participants show a statistically significant difference according to the "Age Group" variable? Do the digital literacy scores of the participants show a statistically significant difference according to the "Economic Status" variable? Do the digital literacy scores of the participants show a statistically significant difference according to the variable of "Using Smart Devices"? Do the digital literacy scores of the participants show a statistically significant difference according to the "Following Digital Technologies" variable?

To evaluate the digital literacy levels of the participants, quantitative research methods, cross-sectional scanning method and relational research method were used. The universe of the research is university students and graduates in Turkey. In this study, one of the sampling methods, data was collected by simple random method, and online survey was preferred as the data collection method. In the study, analyzes were made on the data of 1287 participants obtained as a result of normality analysis and deletion of missing data. $53.5 \%$ of the participants in the study are women and the remaining $46.5 \%$ are men.

As a result of Independent-Samples T Test and ANOVA, it was concluded that the Digital Literacy scores of the male participants were higher than the female participants. In the literature, there are studies that generally conclude that men have a higher level of digital literacy compared to women. According to the education level, graduate students and graduates have higher digital literacy scores than undergraduate students. When we divided the participants into two separate categories as university students and graduates, it was concluded that graduates have higher digital literacy than students. In the study, it was determined that group with the oldest participants had the lowest digital literacy score. There are general views and studies in the literature that the digital literacy of older people is lower than young people. When a comparison is made according to the economic conditions of the participants, it is concluded that the digital literacy scores of the group with the lowest economic level are lower than all other groups. Other groups are similar in digital literacy among themselves. It is concluded that those with a minimum income are generally less likely 


\section{AJIT-e Bilişim Teknolojileri Online Dergisi \\ Academic Journal of Information Tecnology}

2021 Summer/Yaz - Cilt/Vol: 12 - Sayı/Issue: 46

doi) 10.5824/ajite.2021.03.003.x

to have digital literacy compared to high-income individuals, due to the poor purchasing power of digital products.

When the digital literacy scores are analyzed according to the period of starting to use smart devices; It was observed that the digital literacy levels of those who started using devices in the primary school and pre-school period were higher than in all subsequent periods. In addition, it was concluded that the digital literacy scores of those who started using smart devices after university were lower than those who started in university and previous periods. Getting acquainted with digital technologies at an early age has positive effects on digital literacy. It has been observed that those who follow the developments in digital technologies have a very high level of digital literacy compared to those who do not. In addition, when the scores obtained by the participants from the scale according to the way they followed the developments in digital technologies were examined, the scores of the participants who followed the developments through technology magazines were found to be high. Due to the development of digital technologies and the fact that various items in scales will become outdated over time, it is recommended that researchers might update the items in scale on digital literacy with the technological developments and the needs of the society.

\section{GİRIŞ}

Covid-19 salgınıyla birlikte dijital okuryazarlığın var olan önemi daha da artmış ve üzerinde daha da düşünülmesi gereken bir konu haline gelmiştir. Çevrim içi alışveriş sistemleri, robotik araçlarla teslimat, dijital temassız ödeme süreçleri, uzaktan çalışma prensibi, uzaktan eğitim, çevrim içi sağlık hizmetleri, çevrim içi eğlence, dijital vatandaşlık pratikleri, tedarik zincirine dijital katkı, 3D baskı ile üretim, 5G ve iletişim teknolojileri gibi birçok kavram ve hizmet Covid-19 ile birlikte daha da ön plana çıkmıştır. Tüm bu süreçlere ayak uydurabilmek ve onları yönetebilmek için dijital okuryazarlık günümüzün önemli unsurlarında biri haline gelmiştir. Dijital dönüşümün kaçınılmaz bir hale gelmesi, insanları bu teknolojiler konusunda yeniden düşünmeye sevk etmektedir. Örneğin, çevrim içi araştırma şirketi olan ve bünyesinde 1.2 milyon kayıtlı kullanıcı bulunduran DORinsight, Nisan 2020' de yaklaşık 3,600 kullanıcının katıldığ 1 Covid-19 evden çalışma üzerine yaptığı bir araştırmasında bazı dikkat çeken sonuçlara ulaşmıştır. Türkiye'de gerçekleştirilen araştırmaya göre, katılımcıların yüzde 80'ine yakın bölümü dijital olarak evden çalışma modelini desteklemektedir (DORinsight, 2020).

Ekonomik, kültürel, sosyal ve kişisel alanlar başta olmak üzere yaşamın hemen hemen her alanına etki eden dijital okuryazarlığın, öğretilebilir ve ölçülebilir yapıtaşlarıyla ifade edilmesi yapılacak olan uygulamalarda ve atılacak adımlarda önem arz etmektedir. Bu minvalde hangi yetkinliklerin dijital okuryazarlık içinde ifade edilebileceği, bu yetkinliklerin hangilerinin dijital katılımla, çevrim içi öğrenmeyle, dijital çağa uyum sağlamakla, dijital 
teknolojilerin desteklediği toplumsal kalkınmayla ve dijital çağın getirdiği riskleri yönetebilmeyle ilişkili olduğunu ölçebilen araçların varlığına ihtiyaç duyulmaktadır. Bundan dolayı araştırmacılar, yasa koyucular ve AB, OECD gibi uluslararası kurumlar dijital okuryazarlıkların ölçülmesine yönelik çalışmalar yapmaktadır. Bu ölçümler genel olarak;

- $\quad$ İstihdam, kalkınma ve üretkenliği artırmak için gerekli olan dijital yetkinliklerin ortaya çıkarılmasında,

- $\quad$ Toplumdaki bireylerin daha etkili şekilde dijital çağa uyum sağlayabilmesi için yapılan ya da yapılması planlanan etkinliklerin değerlendirilmesinde,

- $\quad$ Eğitim politikalarının dijital çağdaki sosyal ve ekonomik ihtiyaçlara cevap verebilecek şekilde tasarlanmasında,

- Başta eğitimciler ve öğrenciler olmak üzere, tüm vatandaşların dijital okuryazarlıklarının değerlendirilmesi ve toplumun dijital alandaki güçlü ve zayıf yanlarının tespit edilerek ona göre planlama ve uygulama yapılmasında,

- $\quad$ Dijital teknolojilerin ortaya çıkardığı risk ve tehlikelere karşı farkındalık ve önlem almaya yönelik çalışmaların oluşturulmasında,

- Hükümetlerin dijital eylem planları oluşturmasında ve kaynakların daha etkili kullanılmasında imkân ve kolaylık sağlamaktadır.

Türkiye' de de dünyada olduğu gibi dijital okuryazarlığa verilen önem hem kamu hem akademi hem de sektör boyutuyla artmakta ve öğrencilerin ve vatandaşların dijital okuryazarlıklarını ölçmeye yönelik çeşitli çalışmalar yapılmaktadır (Karakuş \& Ocak, 2019; Özerbaş \& Kuralbayeva, 2018; Onursoy, 2018 ; Ertaş, Kiraç, \& Demir, 2019; Kıyıc1, 2008). Bu araştırmada da üniversite öğrencilerinin ve mezunlarının dijital okuryazarlık düzeylerini ölçmek amaçlanmıştır. Bu amaç doğrultusunda Bayrakcı ve Narmanlığlu (2021) tarafından doktora tezi kapsamında geliştirilen Dijital Okuryazarlık Ölçeği'nden yararlanılmıştır. Ayrıca araştırma kapsamında aşağıdaki sorulara cevap aranmıştır:

- $\quad$ Üniversite öğrencilerinin ve mezunlarının dijital okuryazarlık düzeyleri nedir?

- Katılımcıların dijital okuryazarlık puanlarının "Cinsiyet" değişkeni bakımında istatistiksel olarak anlamlı bir fark var midir?

- Katılımcıların dijital okuryazarlık puanları "Eğitim Düzeyi” değişkenine göre istatistiksel olarak anlamlı bir farklılık göstermekte midir?

- Katılımcıların dijital okuryazarlık puanları "Yaş Grubu" değişkenine göre istatistiksel olarak anlamlı bir farklılık göstermekte midir?

- Katılımcıların dijital okuryazarlık puanları “Ekonomik Durum” değişkenine göre istatistiksel olarak anlamlı bir farklılık göstermekte midir?

- Katılımcıların dijital okuryazarlık puanları "Akıllı Cihaz Kullanmaya Başlama Dönemi" değişkenine göre istatistiksel olarak anlamlı bir farklılık göstermekte midir?

- Katılımcıların dijital okuryazarlık puanları “Akıllı Cihaz Kullanmaya Başlama Dönemi" değişkenine göre istatistiksel olarak anlamlı bir farklılık göstermekte midir?

- Katılımcıların dijital okuryazarlık puanları “Dijital Teknolojileri Takip Etme 
Durumu" değişkenine göre istatistiksel olarak anlamlı bir farklılık göstermekte midir?

Dijital okuryazarlık kavramı literatüre ilk kez 1990'ların sonunda Gilster (1997, s. 1) tarafından dâhil edilmiştir (Spante, Hashemi, Lundin, \& Alger, 2018). Gilster (1997, s.2, 34) kitabında kavramı şöyle açıklamaktadır:

“Dijital okuryazarlık, bilgisayar aracılığıyla çeşitli kaynaklardan gelen enformasyonu anlama ve kullanma yeteneği. [...] Kavram okuryazar olmanın ötesinde erişilen enformasyonu değerlendirme ve karşılaşılan problemi çözme becerilerini de kapsamaktadır, bunları yapabilmek için de bir dizi becerileri gerektirir."

From (2015, s. 44) yaşamboyu öğrenme kavramının Avrupa'da yaygınlaşmasıyla birlikte dijital okuryazarlığın 2000'li yıllardan sonra hem raporlarda hem de akademik çalışmalarda daha çok yer aldığını belirtmektedir. Henüz kavramın bilimsel bir temele oturtulamadığını savunarak dijital okuryazarlığı, "en genel tanımla enformasyon ve iletişim teknolojilerini kullanabilme becerisi" olarak tanımlamıştır. Vieru (2015, s. 9) dijital yetkinliği, “istihdam, öğrenme, kişisel gelişim ve topluma katılım için bilişim teknolojisini etkin ve eleştirel bir şekilde kullanma yeteneği" olarak tanımlamıştır.

Avrupa Komisyonu tarafından geliştirilen ve dijital olarak yetkin olmanın ne anlama geldiğini açıklama amacıyla oluşturulan Avrupa Dijital Yetkinlik Çerçevesi (DigComp: the European Digital Competence Framework) ilk olarak 2013'te oluşturulmuştur. Bu çerçeve süreç içinde farklı paydaşlarla proje olarak geliştirilmiş ve vatandaşlara yönelik uygulanmaya başlanmıştır. Amacı Avrupa vatandaşlarının dijital yetkinliklerini geliştirmek, bunun için yasa ve politikalara destek olmak ve hedef gruplara eğitim programları geliştirmek olan DigComp1.0 ve 2.0 literatürde en fazla referans verilen kaynaklardan biri olma özelliğindedir. $\mathrm{Bu}$ raporda dijital yetkinlik kavramı tanımlanırken Ferrari'nin (2012) çalışmasından faydalanılmıştır. Raporda dijital yetkinlik “Analiz etme, problem çözme, iletişim kurma, içerik üretme ve paylaşma, bilgiyi inşa etme gibi işlemlerde iletişim teknolojileri ve dijital medya araçları kullanımı için gerekli olan bilgi, beceri ve tutumlar seti" olarak tanımlanmaktadır.

Bayrakcı ve Narmanlığlu'na (2020) göre dijital okuryazarlık ise;

- $\quad$ Öğrenmeden problem çözmeye, eğlenceden iletişime, vatandaşlık pratiklerinden özel alana kadar pek çok alanda dijital teknolojileri amaca uygun, güvenli ve etkin şekilde kullanabilme,

- Dijital teknolojilerle üretim ve iş birliği yapabilme,

- Dijital teknolojileri ve süreci değerlendirebilme,

- Dijital teknolojilere karşı farkındalığa ve eleştirel bakış açısına sahip olabilme,

- Dijital teknolojilerle ilgili bilişsel, sosyal ve teknik yetkinliklerin bütününü içermektedir. 
Bayrakcı ve Narmanlıŏlu (2021, s. 6) dijital okuryazarlı̆̆ı, “dijital yetkinlikler bütünü” olarak tanımlamakta ve bu geniş tanımı aşağıdaki modelde ifade etmektedir.

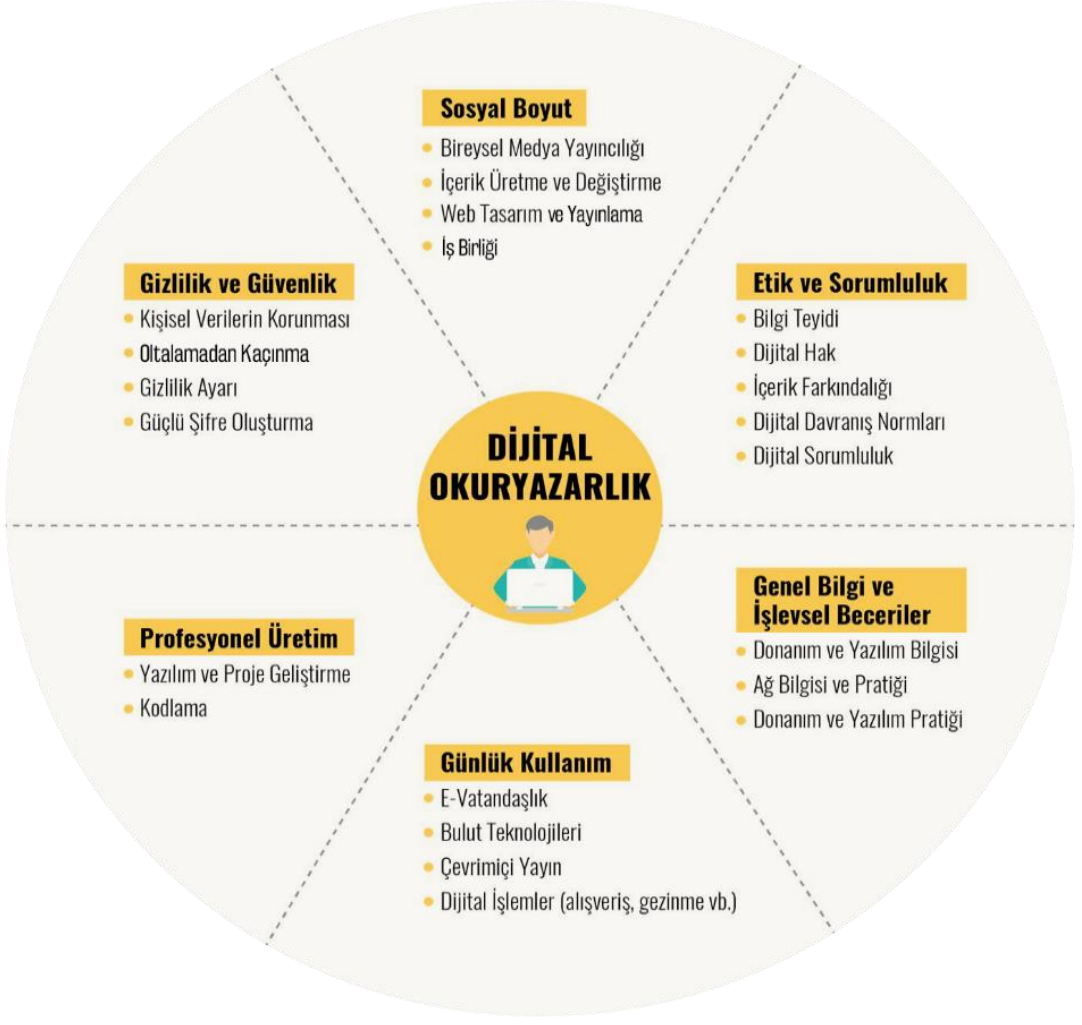

Şekil 1: Dijital Okuryazarlık

\section{YÖNTEM}

Katılımcıların dijital okuryazarlık düzeylerini değerlendirmek için nicel araştırma yaklaşımlarından kesitsel tarama yönteminden ve ilişkisel araştırma yönteminden yararlanılmıştır. Kesitsel tarama yöntemi veri toplama sürecinin örneklem üzerinden bir seferde yapılarak, araştırmanın evreninin herhangi bir andaki durumunu tanımlama firsatı sunmaktadır (Fraenkel \& Wallen, 2011, s. 394). İlişkisel araştırma yönteminde ise iki ya da daha fazla değişkenler arasındaki ilişkilerin belirlenmesi ve bu ilişkilerin yönlerinin tespiti amaçlanmaktadır (Fraenkel \& Wallen, 2011, s. 331).

\section{1. Örneklem ve Veri Toplama Araçları}

Araştırmanın evreni Türkiye' deki üniversite öğrencileri ve mezunlarıdır. Araştırmanın evrenine pratik anlamda erişimin çok zor olmasından dolayı örneklem yöntemine gidilmiştir. Örneklem, araştırmanın yapılacağı evrende yer alan ve evrenin yapısını temsil eden katılımcı grubudur. Bu çalışmada örnekleme yöntemlerinden basit tesadüfi (rastgele) yöntemiyle veri toplanmış, veri toplama yöntemi olarak ise çevrim içi anket tercih edilmiştir. 
Çalışmada araştırmacılar tarafından geliştirilen Dijital Okuryazalırlık Ölçeği (DOYÖ) veri toplama aracı olarak kullanılmıştır. Bu çalışma için yapılan güvenirlik analizi sonucu ölçeğin Cronbach Alpha güvenirlik katsayısı 0.911 olarak hesaplanmıştır. Ölçeğin alt boyutlarının Cronbach Alpha iç tutarlılık değerleri incelendiğinde; etik ve sorumluluk boyutu $\alpha=0,842$; genel bilgi ve işlevsel beceriler boyutu $\alpha=0,875$; günlük kullanım boyutu $\alpha=0,782$; profesyonel üretim boyutu $\alpha=0,719$; gizlilik ve güvenlik boyutu $\alpha=820$ ve sosyal boyut $\alpha=861$ olarak hesaplanmıştır. İç tutarlık katsayısı hesaplamasında Cronbach Alpha değerinin ölçme aracının güvenirliği için alt sınır değeri $\alpha=0.70$ olarak alınmaktadır (Büyüköztürk, 2002; Karasar, 2016; Field, 2009; Tavşanc1l, 2010).

Çalışmada uç değer, normallik analizleri ve eksik verilerin silinmesi neticesinde elde edilen 1287 kişinin verileri üzerinden analizler yapılmıştır. Araştırmaya katılanların \%53,5'i kadın ( $n=688)$ ve geriye kalan \%46,5'i (n=599) erkektir. Katılımcıların \%53,5'u (n=689) lisans öğrencisi, \%43,8'i (n=564) ise lisans mezunudur. Örnekleme dair betimsel istatistik değerleri Tablo 1'de verilmiştir.

\section{VERILERIN ANALIZİ}

Verilerin analizi SPSS 22.0 programında yapılmıştır. Betimsel istatistiklerden yüzde, ortalama, varyans, frekans, standart sapma gibi hesaplamalardan faydalanılmıştır. Betimsel, istatistiksel hipotez testleri ve grafiksel analizler sonucunda elde edilen verinin normal dağılım gösterdiği sonucuna varılmıştır. Normal dağılım olması nedeniyle çıkarımsal istatistik analizlerinde parametrik testler kullanılmaktadır. Parametrik testler arasında ANOVA, Post Hoc, t-testi ve korelasyon analizi tercih edilmiştir. Ayrıca ikiden fazla grup sayısı içeren değişkenlerin (eğitim durumu, yaş grubu vb.) varyansların homojenliğini test etmek için Levene testi kullanılmış, varyanslar homojen ise ANOVA F; homojen değilse Brown-Forsythe testi kullanılmıştır. Ayrıca etki büyüklüğünün hesaplamasında Cohen's d ( $\delta$ ) ve (Cohen's f) eta kare ( $\eta 2)$ formüllerinden yararlanılmıştır (Cohen, 1988).

Tersten puanlanan maddenin bulunmadığı altı alt boyut ve 29 maddeden oluşan dijital okuryazarlık ölçeğinde Likert tipi ölçekleme yaklaşımlarından 5'li Likert ölçeği (Kesinlikle katılıyorum (5), katılıyorum (4), kararsızım (3), katılmıyorum (2), kesinlikle katılmıyorum (1)) şeklindedir. 29 maddeden toplanan toplam puan 29 (29x1) ile 145 (29x5) aralığındadır. Alınan puanlara göre düzeyler aşağıda sıralanmıştır (Ertaş, Kiraç, \& Demir, 2019).

$\begin{array}{ll}1,62-3,07 & \text { Düşük/Kötü } \\ 3,08-3,62 & \text { Orta Altı/Zayıf } \\ 3,63-4,17 & \text { Orta } \\ 4,18-4,72 & \text { Orta Üstü/İyi } \\ 4,73-5,00 & \text { Yüksek/Çok İyi }\end{array}$




\subsection{Bulgular}

Araştırmaya katılanların demografik özelliklerine dair frekansları ve yüzde oranları Tablo 1'de verilmiştir.

Tablo 1: Demografik Değişkenler

\begin{tabular}{|c|c|c|c|}
\hline Demografik Değişkenler & & Frekans & Yüzde (\%) \\
\hline \multirow{2}{*}{ Cinsiyet } & Kadın & 688 & 53,5 \\
\hline & Erkek & 599 & 46,5 \\
\hline \multirow{5}{*}{ Yaş Grubu } & $17-24$ & 816 & 63,4 \\
\hline & $25-32$ & 264 & 20,5 \\
\hline & $33-40$ & 121 & 9,4 \\
\hline & $41-48$ & 67 & 5,2 \\
\hline & 49 Üstü & 19 & 1,5 \\
\hline \multirow{8}{*}{ Eğitim Durumu } & İlkokul/Ortaokul Mezunu & 9 & 0,7 \\
\hline & Lise Mezunu & 25 & 1,9 \\
\hline & Lisans Öğrencisi & 689 & 53,5 \\
\hline & Lisans Mezunu & 323 & 25,1 \\
\hline & Yüksek Lisans Öğrencisi & 114 & 8,9 \\
\hline & Yüksek Lisans Mezunu & 56 & 4,4 \\
\hline & Doktora Öğrencisi & 42 & 3,3 \\
\hline & Doktora Mezunu & 29 & 2,3 \\
\hline \multirow{6}{*}{ Akıllı Cihaz Kullanmaya Başlama Dönemi } & İlkokuldan Önce & 58 & 4,5 \\
\hline & İlkokul Döneminde & 238 & 18,5 \\
\hline & Ortaokul Döneminde & 397 & 30,8 \\
\hline & Lise Döneminde & 378 & 29,4 \\
\hline & Üniversite Döneminde & 156 & 12,1 \\
\hline & Üniversiteden Sonra & 60 & 4,7 \\
\hline \multirow{2}{*}{ Dijital Gelişmeleri Takip Etme Durumu } & Evet & 1027 & 79,8 \\
\hline & Hayır & 260 & 20,2 \\
\hline \multirow{6}{*}{ Dijital Gelişmeleri Takip Etme Biçimi } & $\begin{array}{l}\text { Teknolojik haber yapan Web } \\
\text { siteleri }\end{array}$ & 558 & 35,3 \\
\hline & $\begin{array}{l}\text { Sosyal medyada kurumsal } \\
\text { hesaplar }\end{array}$ & 562 & 35,5 \\
\hline & Sosyal medyada ünlü isimler & 232 & 14,7 \\
\hline & Mail Bültenleri & 115 & 7,3 \\
\hline & Teknoloji dergileri & 73 & 4,6 \\
\hline & $\begin{array}{l}\text { Diğger (Sosyal çevre, haber } \\
\text { vb.) }\end{array}$ & 41 & 2,6 \\
\hline
\end{tabular}


Araştırmaya katılan 1287 kişinin farklı cinsiyetlere, farklı eğitim durumlarına, farklı fakülte türlerine ve farklı akıllı cihazları kullanmaya başlama dönemlerine sahip olmaları araştırmanın geneli temsil etmesi açısından da önem arz etmektedir.

Dijital okuryazarlık ölçeği toplam puanının aritmetik ortalaması olan 3,90 değeri analizlerde DOY Puanı olarak isimlendirilmiştir. Her faktöre ait aritmetik ortalama o faktöre ait ölçek puanını temsil etmektedir. DOY ölçeği kapsamında elde edilen verilere dair betimsel istatistikler Tablo 2' de gösterilmiştir.

Tablo 2: DOYÖ ve Alt Boyutlarına Dair Betimsel Değerler

\begin{tabular}{|c|c|c|c|c|c|c|c|}
\hline & & & Genel & & & & \\
\hline & DOY & Etik & veBilgi & veGünlük & Profesyonel & Gizlilik v & eSosyal \\
\hline & Ortalaması & Sorumluluk & İşlevsel & Kullanım & Üretim & Güvenlik & Boyut \\
\hline & & & Beceriler & & & & \\
\hline$\overline{\text { Ortalama }(\bar{X})}$ & 3,90 & 4,24 & 3,62 & 4,22 & 2,50 & 4,39 & 3,46 \\
\hline Std. Sapma & 0,560 & 0,540 & 1,008 & 0,628 & 1,131 & 0,669 & 0,938 \\
\hline Medyan & 3,93 & 4,29 & 3,67 & 4,33 & 2,50 & 4,50 & 3,50 \\
\hline Mode & 3,86 & 4,43 & 5,00 & 5,00 & 2,00 & 5,00 & 3,50 \\
\hline Çarpiklık &,- 440 & $-1,309$ &,- 361 &,- 854 & ,514 & $-1,390$ &,- 222 \\
\hline Std. Hata & ,068 & 068 & 068 & 068 & ,068 & ,068 &, 068 \\
\hline Basıklık & ,233 & 4,573 & -663 & ,988 &,- 484 & 2,373 &,- 484 \\
\hline Std. Hata & , 136 & ,136 & 136 & ,136 & ,136 & , 136 & ,136 \\
\hline$\overline{\mathbf{N}}$ & 1287 & 1287 & 1287 & 1287 & 1287 & 1287 & 1287 \\
\hline
\end{tabular}

DOY puanı ile alt boyutların puanları incelendiğinde, etik ve sorumluk 4,24, gizlilik güvenlik 4,39 ve günlük kullanım 4,22 aritmetik ortalamaları ile DOY ortalamasından daha yüksektir. Diğer yandan genel bilgi ve işlevsel beceriler boyutu 3,62, sosyal boyutun 3,46 ve en düşük ortalama ile profesyonel üretim boyutunun 2,50'dir. Bunların ortalamaları dijital DOY puanı otamasından düşük olduğu gözlenmiştir. Bu durum katılımcıların profesyonel üretim, iş birliği, teknik ve bilişsel ve teknik yetkinliklerinin daha zayıf olduğunu sonucuna varılmıştır. Diğer yandan ise dijital teknolojileri günlük yaşamda, sorumluluk bilinci içinde güvenli kullanabilme yetkinliklerinin ortalamaya nazaran daha yüksek olduğuna ulaşılmıştır. Sahip olunan farklı değişkenlere göre DOY puanları analiz edilmiştir.

- Katılımcıların dijital okuryazarlık puanlarının "Cinsiyet" değişkeni bakımında istatistiksel olarak anlamlı bir fark var mıdır? 
Tablo 3: Cinsiyete Göre DOY Puanları Bağımsız Örneklem t Testi Sonuçları

\begin{tabular}{llllll}
\hline Cinsiyet & $\bar{X}$ & SS & sd & t & p \\
\hline Kadın & 3,76 & 0,532 & 1285 & 1,519 & 0,00 \\
\hline Erkek & 4,06 & 0,549 & & & \\
\hline Cohens & &
\end{tabular}

Cohen's d etki değeri: $\delta=0.554$

Tablo 3'te görüldüğü üzere katılımcıların dijital okuryazarlık düzeyleri cinsiyet açısından, kadın $(X=3,76$; SS=0,532) ve erkek $(X=4,06$; $S S=0,549)$ arasında istatistiksel olarak anlamlı bir farklılık bulunmaktadır [ $\mathrm{t}(1285)=1,519 ; \mathrm{p}<0,05]$. Genel olarak erkek katılımcların dijital okuryazarlık düzeylerinin daha yüksek olduğu sonucuna varılmıştır. Cinsiyetlere göre DOY puanları arasındaki anlamlı farklılığın büyüklüğünün ne olduğuna ulaşmak için yapılan Cohen's d etki değeri testi sonucu $\delta=0.554$ çıkmıştır. Cinsiyet değişkenin orta düzeyde etki değerine $(\delta=0.554)$ sahip anlamlı bir farklılık oluşturduğu söylenebilir.

- Katılımcıların dijital okuryazarlık puanları "Eğitim Düzeyi" değişkenine göre istatistiksel olarak anlamlı bir farklılık göstermekte midir?

Eğitim düzeyine göre katılımcların dijital okuryazarlık puanlarını test etmek için önce homojenlik testi yapılmıştır. Varyansların homojen olduğu (Levene:1,079; p>0,05) sonucuna ulaşılmış ve bu nedenle ANOVA F istatistiği dikkate alınmıştır.

Tablo 4: Eğitim Durumuna Göre DOY Puanları ANOVA Sonuçları

\begin{tabular}{|c|c|c|c|c|c|c|c|c|c|}
\hline Eğitim Durumu & $\mathbf{N}$ & $\bar{x}$ & SS & Varyans & $\begin{array}{l}\text { Kareler } \\
\text { Toplamı } \\
\text { (K. T.) }\end{array}$ & sd & $\mathbf{F}$ & p & $\begin{array}{l}\text { Post Hoc } \\
\text { Anlamlı } \\
\text { Farklılık }\end{array}$ \\
\hline $\begin{array}{l}\text { A. İlkokul/Ortaokul } \\
\text { Mezunu }\end{array}$ & 9 & 3,21 & 0,83 & $\begin{array}{l}\text { Gruplar } \\
\text { Arası }\end{array}$ & 14,104 & 7 & 6,599 & 0,000 & $\mathrm{E}>\mathrm{C}$ \\
\hline B. Lise Mezunu & 25 & 3,82 & 0,41 & Grup İçi & 390,504 & 1279 & & & $\mathrm{~F}>\mathrm{C}$ \\
\hline C. Lisans Öğrencisi & 689 & 3,84 & 0,56 & Toplam & 404,607 & 1286 & & & $\mathrm{C}, \mathrm{D}, \mathrm{E}, \mathrm{F}, \mathrm{G}>\mathrm{A}$ \\
\hline D. Lisans Mezunu & 323 & 3,95 & 0,56 & & & & & & \\
\hline $\begin{array}{lrl}\text { E. } & \text { Yüksek } & \text { Lisans } \\
\text { Öğrencisi } & \\
\end{array}$ & 114 & 4,00 & 0,52 & & & & & & \\
\hline $\begin{array}{ll}\text { F. Yüksek Lisans } \\
\text { Mezunu }\end{array}$ & 56 & 4,12 & 0,57 & & & & & & \\
\hline $\begin{array}{ll}\text { G. } & \text { Doktora } \\
\text { Öğrencisi } & \\
\end{array}$ & 42 & 4,15 & 0,53 & & & & & & \\
\hline H. Doktora Mezunu & 29 & 3,81 & 0,52 & & & & & & \\
\hline Toplam & 1287 & 3,90 & 0,56 & & & & & & \\
\hline
\end{tabular}

Etki Değeri: $\eta^{2}=0,0348$ 


\section{AJIT-e Bilişim Teknolojileri Online Dergisi \\ Academic Journal of Information Tecnology}

2021 Summer/Yaz - Cilt/Vol: 12 - Sayı/Issue: 46

doi) 10.5824/ajite.2021.03.003.x

Tablo 4'te yer alan verilere göre, "eğitim durumu" değişkenine göre katılımcıların dijital okuryazarlık puanları arasında istatistiksel olarak anlamlı bir fark bulunmuştur. [t(71279-1286)=6,599; $\mathrm{p}<0,05]$. Eğitim durumuna göre DOY puanları arasındaki anlamlı farklılığın büyüklüğünün ne olduğuna ulaşmak için yapılan eta kare $(\eta 2)$ etki değeri testi sonucu $\eta 2=$ $0,0348)$ çıkmıştır. Bu değer ANOVA testi sonucunda eğitim düzeyi grupları arasında orta düzeyde etki değeri $(\eta 2=0,0348)$ olan anlamlı bir farklılığın var olduğunu göstermektedir.

Hangi gruplar arasında anlamlı farklılığın var olduğunu bulmak için Post Hoc testlerinden Gabriel testi yapılmıştır. Eğitim durumuna ait grupların örneklem sayıları birbirinden çok farklı olduğu için bu test tercih edilmiştir. Bu test sonucunda doktora mezunları $(X=3,81)$ hariç tüm grupların ilkokul/ortaokul mezunları $(X=3,21)$ ile anlamlı farklılık göstermektedir $(C, D, E, F, G>A)$. Ayrıca yüksek lisans öğrencilerinin $(X=4,00)$ ve mezunlarının $(X=3,21)$ lisans öğrencileri $(X=3,84)$ ile anlamlı farklılık gösterdiği $(E>C, F>C)$ sonucuna ulaşılmıştır.

Ayrıca genel olarak "Lisans öğrencileri ile mezunları arasında dijital okuryazarlık puanları istatistiksel olarak anlamlı bir farklılık göstermekte midir?" sorusunun cevabı aranmıştır. Bu minvalde yüksek lisans ve doktora öğrencileri ile mezunları "lisans mezunu" olarak değerlendirilmiştir. Yapılan bağımsız örneklem t-testi sonucunda lisans öğrencileri ile lisans mezunları arasında istatistiksel olarak anlamlı farklılık bulunmuştur ( $\mathrm{t}=4,502, \mathrm{df}=1251$, $p>0,05)$. Lisans mezunlarının $\left(x^{-}=3,99\right)$ DOY puanlarının lisans öğrencilerine $\left(x^{-}=3,84\right)$ nazaran daha yüksek olduğu sonucuna ulaşılmıştır.

Katılımcıların dijital okuryazarlık puanları "Yaş Grubu" değişkenine göre istatistiksel olarak anlamlı bir farklılık göstermekte midir?

Katılımcıların doğrudan yaşı sorulmuştur ancak analizlerde kolaylık sağlaması nedeniyle gruplama yapılmıştır. Eğitim düzeyine göre katılımcıların dijital okuryazarlık puanlarını test etmek için önce homojenlik testi yapılmıştır. Varyansların homojen olmadığ (Levene:4,013; $\mathrm{p}<0,05)$ sonucuna varılmıştır. Varyanslar homojen olmadığı için BrownForsthe Testi istatistiği dikkate alınmış. $\mathrm{p}<0,005$ olması nedeniyle yaş grupları arasında DOY puanı bakımından anlamlı farklılıklar olduğu sonucuna varılmıştır.

Yaş gruplarına göre DOY puanları arasındaki anlamlı farklılığın büyüklügüünün ne olduğuna ulaşmak için yapılan eta kare ( 2 ) etki değeri testi sonucu $\eta 2=0,0271$ çıkmıştır. Bu değer ANOVA testi sonucunda yaş grupları arasında orta düzeyde etki değeri $(\eta 2=0,0271)$ olan anlamlı bir farklılık bulunmuştur.

Varyansların durumundan dolayı çoklu karşılaştırma testlerinden Dunnett's T3 testi uygulanarak hangi yaş grupları arasında anlamlı farklılığın olduğu tespit edilmiş ve Tablo 5 'te verilmiştir. 
Tablo 5: Yaş Grubuna Göre DOY Puanları ANOVA Sonuçları

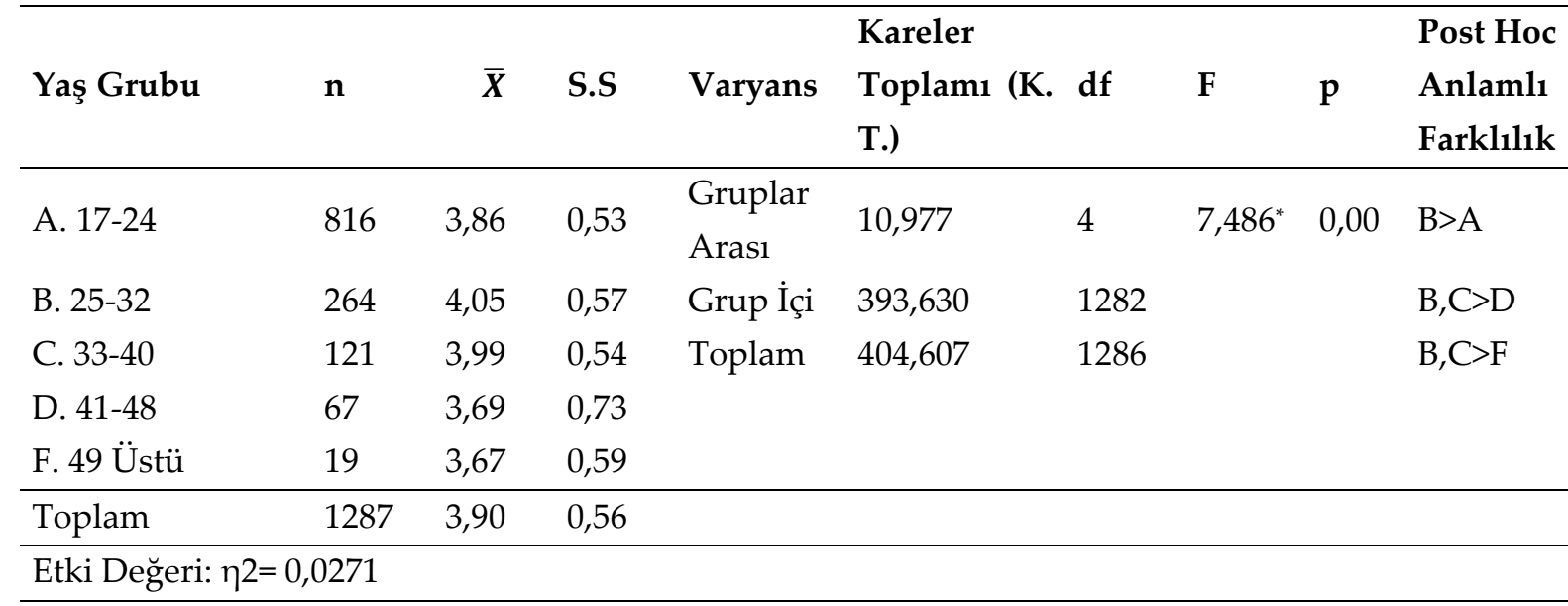

* Brown-Forsythe Testi İstatistiği

Yapılan test sonucunda 25-32 yaş grubu 17-24 yaş grubundan (B>A), 41-48 yaş grubundan (B>D) ve 49 Üstü yaş grubundan istatistiksel olarak anlamlı bir şekilde DOY puanı daha yüksektir. Aynı zamanda 33-40 yaş grubu da 41-48 (C>D) ve 49 Üstü (C>E) yaş grubundan anlamlı bir şekilde yüksek değere sahiptir.

Yaş grubu değişkeni ile eğitim durumu değişkenini Ki Kare Uyum testi incelendiğinde değişkenlerin arasında anlamlı bir ilişki olduğu tespit edilmiştir(p<0,05). Çapraz tablolama sonuçlarına göre 17-24 yaş aralığındaki katılımcıların \%79,2'si lisans öğrenci, 25-32 yaş grubunun ise \%47,3'ü lisans mezunu ve \%32,9'ü lisansüstü öğrencisidir. Bu durum 24-32 yaş grubunun 17-24 arası yaş grubundan daha yüksek DOY puanına sahip olmasının olası nedeni olarak değerlendirilmektedir.

- Katılımcıların dijital okuryazarlık puanları “Ekonomik Durum” değişkenine göre istatistiksel olarak anlamlı bir farklılık göstermekte midir?

Ekonomik durumlarına göre dijital okuryazarlık puanlarını test etmek için önce homojenlik testi yapılmıştır. Varyansların homojen olduğu (Levene:0,409; p>0,05) sonucuna ulaşılmış ve bu nedenle ANOVA F istatistiği dikkate alınmıştır. 
Tablo 6: Ekonomik Duruma Göre DOY Puanları ANOVA Sonuçları

\begin{tabular}{lcccllllll}
\hline Eğitim Durumu & $\mathbf{n}$ & $\overline{\boldsymbol{X}}$ & S.S & Varyans & $\begin{array}{l}\text { Kareler } \\
\text { Toplamı } \\
\text { (K. T.) }\end{array}$ & df & F & p & $\begin{array}{l}\text { Post Hoc } \\
\text { Anlamlı } \\
\text { Farklılık }\end{array}$ \\
\hline A. 0-3000 TL & 433 & 3,79 & 0,56 & $\begin{array}{l}\text { Gruplar } \\
\text { Arası }\end{array}$ & 9,520 & 5 & 6,173 & 0,000 & $\begin{array}{l}\text { A< } \\
\text { B,C,D,E,F }\end{array}$ \\
B. 3001-6000 TL & 451 & 3,94 & 0,55 & Grup İçi & 395,088 & 1281 & & & \\
C. 6001-9000 TL & 210 & 3,99 & 0,56 & Toplam & 404,607 & 1286 & & \\
D. 9001-12 000 TL & 108 & 3,92 & 0,58 & & & & & & \\
E. 12 001-15 000 TL & 35 & 4,07 & 0,50 & & & & & & \\
F. 15 000 üzeri TL & 50 & 4,02 & 0,54 & & & & & & \\
\hline Toplam & 1287 & 3,90 & 0,56 & & & & & & \\
\hline
\end{tabular}

Etki Değeri: $\eta^{2}=0,0235$

Tablo 6'daki verilere göre, "ekonomik durum" değişkenine göre katılımcıların dijital okuryazarlık puanları arasında istatistiksel olarak anlamlı bir fark bulunmuştur ( $\mathrm{F}=6,173$; $\mathrm{p}<0,05)$. Ekonomik duruma göre DOY puanları arasındaki anlamlı farklılığın büyüklüğünün nasıl olduğuna ulaşmak için yapılan eta kare ( $\eta 2)$ etki değeri testi sonucu $\eta 2=0,0235$ ) çıkmıştır. $\mathrm{Bu}$ değer ANOVA testi sonucunda gelir düzeyinin DOY puanı üzerinde orta düzeyde etki değeri $(\eta 2=0,0235)$ olan anlamlı bir farklılık söz konusudur.

Yapılan test sonucunda, aylık gelir durumu 0-3000 TL olanlar ile diğer tüm gruplar arasında anlamlı bir farklılık vardır ve gelir durumu en düşük olan bu grubun DOY puanının da istatistiksel olarak en düşük düzeyde olduğu sonucuna varılmıştır.

- Katılımcıların dijital okuryazarlık puanları “Akıllı Cihaz Kullanmaya Başlama Dönemi” değişkenine göre istatistiksel olarak anlamlı bir farklılık göstermekte midir?

Akıllı cihaz kullanmaya başlama dönemine göre katılımcıların dijital okuryazarlık puanlarını test etmek için önce homojenlik testi yapılmıştır. Varyansların homojen olmadığı (Levene:2,451; $\mathrm{p}<0,05)$ sonucuna varılmıştır. Varyanslar homojen olmadığı için BrownForsthe Testi istatistiği dikkate alınmıs. $\mathrm{p}<0,005$ olması nedeniyle akıllı cihaz kullanmaya başlama dönemi ile DOY puanı bakımından anlamlı farklılıklar olduğu sonucuna varılmıştır.

Akıllı cihaz kullanmaya başlama dönemlerine göre DOY puanları arasındaki anlamlı farklılığın büyüklüğünün ne olduğuna ulaşmak için yapılan eta kare ( 2 2) etki değeri testi sonucu $\eta 2=0,074$ çıkmıştır. Bu değer ANOVA testi sonucunda akıllı cihaz kullanmaya başlama dönemleri arasında yüksek düzeyde etki değeri $(\eta 2=0,074)$ olan anlamlı bir farklılık bulunduğunu göstermektedir. 
Tablo 7: Akıllı Cihaz Kullanmaya Başlama Dönemine Göre DOY Puanları ANOVA Sonuçları

\begin{tabular}{|c|c|c|c|c|c|c|c|c|c|}
\hline Dönem & $\mathbf{n}$ & $\bar{X}$ & S.S & Varyans & $\begin{array}{l}\text { Kareler } \\
\text { Toplamı } \\
\text { (К. T.) }\end{array}$ & df & $\mathbf{F}$ & $\mathrm{p}$ & $\begin{array}{l}\text { Post Hoc } \\
\text { Anlamlı } \\
\text { Farklılık }\end{array}$ \\
\hline A. İlkokul Öncesi & 58 & 4,29 & 0,47 & $\begin{array}{l}\text { Gruplar } \\
\text { Arası }\end{array}$ & 29,516 & 5 & $20,265^{*}$ & 0,00 & $\mathrm{~A}>\mathrm{B}, \mathrm{C}, \mathrm{D}, \mathrm{E}, \mathrm{F}$ \\
\hline B. İlkokul & 238 & 4,08 & 0,48 & Grup İçi & 375,092 & 1281 & & & $\mathrm{~B}>\mathrm{C}, \mathrm{D}, \mathrm{E}, \mathrm{F}$ \\
\hline C. Ortaokul & 397 & 3,91 & 0,55 & Toplam & 404,607 & 1286 & & & $\mathrm{C}>\mathrm{F}$ \\
\hline D. Lise & 378 & 3,81 & 0,54 & & & & & & $\mathrm{D}>\mathrm{F}$ \\
\hline E. Üniversite & 156 & 3,81 & 0,62 & & & & & & $\mathrm{E}>\mathrm{F}$ \\
\hline $\begin{array}{ll}\text { F. } & \text { Üniversite } \\
\text { Sonrası } & \end{array}$ & 60 & 3,54 & 0,56 & & & & & & \\
\hline Toplam & 1287 & 3,90 & 0,56 & & & & & & \\
\hline
\end{tabular}

* Brown-Forsythe Testi İstatistiği

Etki Değeri: $\eta 2=0,074$

Hangi gruplar arasında anlamlı farklılığın var olduğunu bulmak için çoklu karşılaştırma testlerinden Dunnett's T3 testi yapılmıştır. Bu test sonucuna göre; akıllı cihaz kullanmaya başlama dönemi ne kadar erken ise diğer dönemlere göre anlamlı derecede DOY puanı yüksek olduğuna ulaşılmıştır. Akıllı cihaz kullanmaya ilkokul öncesinde başlayanların DOY puanları sonraki diğer tüm dönemlerden anlamlı bir şekilde yüksektir $(A>B, C, D, E, F)$. Ayrıca ilkokul döneminde başlayanlar, sonraki dönemlerin tamamından anlamlı şekilde yüksek olduğu sonucuna varılmıştır (B>C,D,E,F). Akıllı cihaz kullanmaya ortaokul, lise ve üniversite dönemlerinde başlayanların kendi aralarında anlamlı bir farklılık olmasa da bu üç dönemde akıllı cihaz kullanmaya başlayanlar üniversiteden sonra başlayanlara nazaran anlamlı şekilde yüksektir ( $\mathrm{F}<\mathrm{C}, \mathrm{C}, \mathrm{E})$.

- Katılımciların dijital okuryazarlık puanlarıyla "Akıllı Cihaz Kullanmaya Başlama Dönemi” değişkeni arasında istatistiksel olarak anlamlı bir ilişki var mıdır?

DOY puanı normal dağılım gösterdiği için Pearson ilişki testi uygulanmış ve sonuçları Tablo 8'de verilmiştir.

Tablo 8: Akıllı Cihaz Kullanmaya Başlama Dönemi ve DOY Puanı İlişki Testi Sonuçları

\begin{tabular}{lclc}
\hline & & \multicolumn{2}{c}{ Akıllı Cihaz Kullanmaya } \\
& & Başlama Dönemi & \\
\hline Akıllı & Cihaz Pearson Korelasyon & 1 &,$- 255^{* *}$ \\
Kullanmaya & BaşlamaAnlamlılık Değeri & & 0,000 \\
Dönemi & $\mathrm{N}$ & 1287 & 1287 \\
\hline \multirow{2}{*}{ DOY Puanı } & Pearson Korelasyon &,$- 255^{* *}$ & 1 \\
& Anlamlılık Değeri & 0,000 & 1287 \\
\hline
\end{tabular}

\footnotetext{
** Korelasyon 0,01 düzeyinde anlamlıdır (2-uçlu).
} 
Pearson ilişki testi anlamlılık değerinin $p<0,05$ çıkması akıllı cihaz kullanmaya başlama dönemi ile DOY puanları arasında istatistiksel olarak anlamlı bir ilişki olduğunu işaret etmektedir. İlişkinin kuvvetini ve yönünü ifade eden ilişki katsayısı r= -0,255'tir. Bu değer iki değişken arasında negatif yönlü ve çok zayıf bir ilişkinin varlığını göstermektedir. Yani akıllı cihaz başlama dönemi ne kadar erkense, DOY puanı da o kadar yüksek olduğu sonucuna ulaşılmıştır.

- Katılımcıların dijital okuryazarlık puanları "Dijital Teknolojileri Takip Etme Durumu" değişkenine göre istatistiksel olarak anlamlı bir farklılık göstermekte midir?

Yapılan bağımsız örneklem $\mathrm{t}$ - testi sonucunda anlamlılık değerinin $\mathrm{p}<0,05$ çıkması nedeniyle dijital teknolojilerle ilgili gelişmeleri takip edenlerle etmeyenler arasında istatistiksel olarak anlamlı farklılık olduğu sonucuna varılmıştır.

Dijital teknolojilerle ilgili gelişmeleri takip edenlerle etmeyenlerin DOY puanları arasındaki anlamlı farklılığın büyüklüğünün ne olduğuna ulaşmak için yapılan Cohen's d etki değeri testi sonucu $\delta=0,8978$ çıkmıştır. Yapılan bağımsız örneklem t-testi sonucunda dijital gelişmeleri takip etme durumunun DOY puanı üzerinde yüksek düzeyde etki değeri $(\delta=$ 0.8978) olan anlamlı bir farklılık bulunmuştur.

Çalışmada katılımcılar dijital teknolojilerle ilgili gelişmeleri takip edip etmedikleri maddesinden sonra takip ederken hangi yöntemi tercih ettikleri sorulmuştur. Birden fazla yöntem seçme hakkı verilen soruda, katılımcıların dijital teknolojileri takip ederken genel olarak teknoloji dergileri, tekno haber yapan web siteleri, e-posta bültenleri, sosyal medyada ünlü isimleri ve sosyal medyada kurumsal hesapları tercih ettikleri sonucuna varılmıştır. Katılımcların teknolojik gelişmeleri takip etme biçimlerine göre DOY puanları Tablo 9'da verilmiştir.

Tablo 9: Dijital Teknolojileri Takip Etme Biçimlerine Göre DOY Puanları

\begin{tabular}{ll}
\hline Dijital Teknolojileri Takip Etme Biçimi & $\begin{array}{l}\text { DOYÖ } \\
\text { Puanı }\end{array}$ \\
\hline Teknoloji Dergileri & 4,35 \\
Tekno Haber Yapan Web Siteleri & 4,12 \\
E-Posta Bültenleri & 4,28 \\
Sosyal Medyada Ünlü İsimler & 4,02 \\
Sosyal Medyada Kurumsal Hesaplar & 4,01 \\
\hline
\end{tabular}

Dijital teknolojilerle ilgili gelişmeleri takip etme biçimlerine göre katılımcıların ölçekten ve alt boyutlarından aldıkları puanlar incelendiğinde teknoloji dergileri vasıtasıyla takip edenler her hem DOY puanı bakımından hem de alt boyut puanları bakımından yüksek 
olduğuna ulaşılmıştır. Mail bültenleri üzerinden dijital gelişmeleri takip edenler ise teknoloji dergilerinden sonraki en yüksek ortalamalara sahiptir. Sosyal medyada ünlü isimlerden ya da kurumsal hesaplardan dijital gelişmeleri takip edenlerin puanlarının birbirine yakın olduğu ve diğer takip etme biçimlerine nazaran daha düşük olduğu gözlenmiştir.

\section{TARTIŞMA VE SONUÇ}

Bu çalışmanın ana konusu olan dijital okuryazarlık kavramına dair literatürde standart tek bir tanımın olmaması dikkat çekmektedir. 2000'li yıllar öncesinde dijital okuryazarlık daha çok bilgisayar kullanma becerisi olarak ifade edilirken, özellikle Web 2.0 ve mobil teknolojilerin hayatımızın her alanına nüfuz etmesiyle birlikte dijital okuryazarlık kavramının bilgisayar kullanma becerisinden çok daha geniş anlamlar barındırdığı sonucuna ulaşılmıştır. Süreç içinde yapılan tanımlamalar bilgi, beceri, tutum, eleştirel düşünce, teknik, bilişsel, sosyal, farkındalık, uyum, iletişim, iş birliği ve yetkinlik gibi kavramları da kapsayama başlamıştır. Kavramsal çerçevenin keskin olarak çizilememesindeki en önemli neden ise dijital teknolojilerin dinamik bir yapıda olması ve sürekli gelişim halinde olması olarak düşünülmektedir. Bu çalışmada da dijital okuryazarlık kavramı diğer okuryazarlıklara çatı görevinde ve dijital yetkinlikler bütünü olarak değerlendirilmiştir.

Yapılan araştırma sonucunda erkek katılımcıların DOY puanlarının kadınlardan daha yüksek olduğu sonucuna ulaşılmıştır. Literatürde de genel olarak erkeklerin kadınlara nazaran daha yüksek düzeyde dijital okuryazarlığa sahip olduğu sonucuna erişen çalışmalar görülmektedir (Acar, 2015; Çetin, Çalışkan ve Menzi, 2012; Kıyıcı, 2008; Ocak ve Karakuş, 2019; Schonard, 2018; Tekin ve Polat, 2017; Timur ve Timur, 2014). Bunun olası nedenleri ise erkeklerin bilgisayar oyunlarını daha fazla tercih etmesi, bilişim teknolojileriyle ilgili fakültelere ve mesleklere erkeklerin daha fazla ilgi göstermesi ve bu sektörün erkek egemenliğinde devam etmesidir.

Eğitim durumuna göre yüksek lisans öğrencileri ve mezunlarının lisans öğrencilerine kıyasla daha yüksek DOY puanına sahip olduğu; ilkokul ve ortaokul mezunlarının ise düşük DOY puanı aldıkları görülmüştür. Araştırmaya katılanları üniversite öğrencisi ve üniversite mezunu olarak iki ayrı kategoriye ayırdığımızda, lisans mezunlarının lisans öğrencilerinden daha yüksek dijital okuryazarlığa sahip olduğu sonucuna ulaşılmıştır. Bu durumun olası nedenleri arasında mezunların istihdamlarında ve sektörlerinde daha çok dijital teknolojileri kullanmaları ve hizmet içi eğitim ve kurslarla dijital yetkinliklerinin desteklenmesi gösterilebilir. Yeşildal (2018) ve Horrigan (2016) yaptıkları çalışmalarda lisans ve lisansüstü eğitimi olanların, lise ve ortaokul ve ilkokul mezunlarına kıyasla daha yüksek dijital okuryazarlığa sahip olduğuna ulaşmıştır.

Yaş gruplarına göre incelendiğinde 25-32 ve 33-40 yaş gruplarının 49 yaş üstündekilerden ve 24 yaş altındakilerden daha yüksek DOY puanına sahip olduğu sonucuna varılmıştır. Ayrıca en ileri yaş grubunun en düşük DOY puanına sahip olduğu tespit 
edilmiştir. Literatürde ileri yaşlardakilerin dijital okuryazarlıklarının gençlere nazaran daha düşük olduğu yönünde genel görüş ve çalışmalar yer almaktadır (Ertaş, Kiraç, \& Demir, 2019; Horrigan, 2016; Nasah, DaCosta, Kinsell, \& Seok, 2010; Marsh, Hannon, Lewis, \& Ritchie, 2017;). Yaş değişkeninde ileri yaşların DOY puanlarının gençlere nazaran düşük olmasında olası neden dijital teknolojilerle geç tanışmış olmalarıdır.

Katılımcıların ekonomik durumlarına göre dijital okuryazarlıkları mukayese edildiğinde (0-3000 TL) aylık geliri olanların DOY puanlarının diğer tüm gruplardan düşük olduğu sonucuna varılmıştır. Diğer grupların kendi aralarında dijital okuryazarlık bakımından benzerdir. Asgari gelir düzeyine sahip olanların genel olarak dijital ürünleri alım gücünün zayıf olması nedeniyle dijital okuryazarlıklarının yüksek gelirli bireylere nazaran daha düşük olduğu sonucuna varılmıştır (Kıyıcı, 2008; Ocak \& Karakuş, 2019).

Akıllı cihaz kullanmaya başlama dönemine göre DOY puanları incelendiğinde; ilkokul ve öncesi dönemde cihaz kullanmaya başlayanların dijital okuryazarlık düzeylerinin sonraki tüm dönemlerden daha yüksek olduğuna görülmüş̧tür. Ayrıca akıllı cihaz kullanmaya üniversiteden sonra başlayanların DOY puanlarının üniversite döneminde ve önceki dönemlerde başlayanlardan düşük olduğu sonucuna varılmıştır. Erken yaşta dijital teknolojilerle tanışmış olmanın avantajları olduğu gibi dezavantajları da literatürde çok önemli yer kaplamaktadır (Gillen ve diğerleri; 2018; Pereira, Ramos ve Marsh, 2016).

Dijital teknolojilerle ilgili gelişmeleri takip edenlerin, takip etmeyenlere nazaran oldukça yüksek düzeyde dijital okuryazarlığa sahip olduğu görülmüştür. Ayrıca dijital teknolojilerle ilgili gelişmeleri takip etme biçimlerine göre katılımcıların ölçekten aldıkları puanlar incelendiğinde teknoloji dergileri vasıtasıyla gelişmeleri takip edenler e-posta bültenleri, web siteleri ve sosyal medya mecraları vasıtasıyla takip edenlere göre daha fazla dijital okuryazarlık puanına sahiptir. Yaman (2019) sosyal bilgiler öğretmelerine yönelik yaptığı çalışmada benzer sonuçlar elde etmiştir. Teknoloji dergilerinden dijital gelişmeleri takip edenlerin daha yüksek düzeyde dijital okuryazarlıklarının en önemli nedenin bu söz konusu grubun belli bir amaç doğrultusunda dijital teknolojileri takip etikleri düşünülmektedir.

Bu çalışmadan çıkan sonuçlar neticesinde aşağıdaki uygulamalar önerilmektedir.

- Cinsiyetler arasındaki dijital farkın giderilmesi adına öncelikle sektörün cinsiyet tekelciliğinden arındıracak doğru toplumsal politikalar üretilmesi ve kadınlara yönelik eğitimler düzenlenmesi önerilmektedir.

- Özellikle eğitim ve iletişim fakültelerinin müfredatına dijital okuryazarlıkla ilgili derslerin ve dijital teknolojilerin mesleki yaşamlarında daha etkin kullanılmasına yönelik uygulamalı eğitimlerin verilmesi önerilmektedir. 
- Bölgesel gelişim farklarını temel alan dijital okuryazarlık çalışmaları yapılması önerilmektedir.

- Çocukların erken yaşta akıllı cihaz kullanmaları hususunda okul öncesi eğitimin desteklenmesi, öğretmenlere ve ebeveynlere yönelik dijital teknolojilerin amaçlı kullanımı, sınırlılıkları, kontrol mekanizmaları ve karşılaşılabilecek güçlüklerle ilgili eğitim ve seminerler verilerek, farkındalık oluşturulması önerilmektedir.

Son olarak dijital teknolojilerin gelişim halinde olması ve zaman içinde ölçeklerdeki çeşitli maddelerin güncelliğini kaybedecek olması nedeniyle araştırmacıların teknolojik gelişmelere ve toplumun ihtiyaçlarına uygun şekilde dijital okuryazarlıkla ilgili çalışmaları güncellemeleri önerilmektedir.

\section{KAYNAKÇA}

Acar, Ç. \& Şïmşek, N. (2015) Anne ve babaların ilkokul ortaokul ve lise öğrencisi çocukları ile kendilerinin dijital okuryazarlkklarına ilişkin görüşleri. Yayınlanmamış Yüksek Lisans Tezi, Ankara Üniversitesi Eğitim Bilimleri Enstitüsü Bilgisayar ve Öğretim Teknolojileri Eğitimi Anabilim Dalı Eğitim Teknolojisi Program1 . https://dspace.ankara.edu.tr/xmlui/handle/20.500.12575/32000.

Bayrakcı, S., \& Narmanlıoğlu, H. (2021). Digital Literacy as Whole of Digital Competences: Scale Development Study. Düşünce ve Toplum Sosyal Bilimler Dergisi, 3(4), 1-30.

Cohen, D. (1988). Statistical power analysis for the behavioral sciences (2nd ed.). Hillsdale: NJ: Erlbaum.

Çetin, O., Çalışkan, E., \& Menzi, N. (2012). Öğretmen Adaylarının Teknoloji Yeterlilikleri ile Teknolojiye Yönelik Tutumları Arasındaki İlişki. Ilköğretim Online, 273-291.

DORinsight. (2020). DORinside. https://epnext.com/salgin-sonrasi-is-yasami-raporu-evden-calismayisevdik/adresinden alınd 1

Ertaş, H., Kiraç, R., \& Demir, R. (2019). Dijital Okuryazarlık ve E-Sağlık Okuryazarlığı Arasındaki İlişkinin İncelenmesi. 3. Uluslarararası 13. Ulusal Sağlık ve Hastane İdaresi Kongresi (s. 557-570). Sakarya: Sakarya Üniversitesi.

Eshet-Alkalai, Y. (2004). Digital literacy: A conceptual framework for survival skills in the digital era. Journal of educational multimedia and hypermedia, 93-106.

Eşgi, N. (2013). Dijital Yerli Çocukların ve Dijital Göçmen Ebeveynlerinin İnternet Bağımlılı̆̆ına İlişkin Algılarının Karşılaştırılması. Hacettepe Üniversitesi Eğitim Fakültesi Dergisi, 181-194.

Ferrari, A. (2012). Digital Competence in Practice: An Analysis of Frameworks. Luxembourg. Publications Office of the European Union.

Fraenkel, J. R., \& Wallen, N. E. (2011). How to Design and Evaluate Research in Education. McGraw-Hill Humanities/Social Sciences/Languages.

From, J. (2015). Pedagogical Digital Competence-Between Values, Knowledge and Skills. Higher Education Studies, 43-50.

Gillen, J., Marsh, J., Bus, J., Castro, T., \& Dardanou, E. (2018). Digital Literacy and Young Children: Towards Better Understandings of the Benefits and Challenges of Digital Technologies in Homes and Early Years Settings. 


\section{AJIT-e Bilişim Teknolojileri Online Dergisi \\ Academic Journal of Information Tecnology \\ 2021 Summer/Yaz - Cilt/Vol: 12 - Sayı/Issue: 46 \\ doi) 10.5824/ajite.2021.03.003.x}

https://e-

space.mmu.ac.uk/624237/1/Gillen_Arnott_PB_2018_Digital_Literacy_and_Young_Children_T owards_Better_Understandings_of_the_Benefits.pdf adresinden alındı

Gilster, P. (1977). Digital Literacy. Wiley Computer Publications.

Hamutoğlu, N. B., Güngören, Ö. C., Uyanık, G. K., \& Erdoğan, D. G. (2017). Dijital Okuryazarlık Ölçeği: Türkçe 'ye Uyarlama Çalışması. Ege Ĕ̆itim Dergisi, 408- 429.

Horrigan, J. B. (2016). Digital Readiness Gaps. Pew Research Center.

JISC. (2011). Developing Digital Literacies: Briefing Paper in support of JISC Grant Funding 4/11. JISC.

Kıyıcı, M. (2008). Öğretmen Adaylarının Sayısal Okuryazarlık Düzeylerinin Belirlenmesi. Yayınlanmış Doktora Tezi, Anadolu Üniversitesi Eğitim Bilimleri Enstitüsü.

Marsh, J., Hannon, P., Lewis, M., \& Ritchie, L. (2017). Young children's initiation into family literacy practices in the digital age. Journal of Early Childhood Research, 15(1), 47-60.

Nasah, A., DaCosta, B., Kinsell, C., \& Seok, S. (2010). The digital literacy debate: an investigation of digital propensity and information and communication technology. Education Tech Research Dev, 531-555.

Ocak, G., \& Karakuş, G. (2019). Öğretmen Adaylarının Dijital Okuryazarlık Öz-yeterlilik Becerilerinin Farklı Değişkenler Açısından İncelenmesi. Afyon Kocatepe Üniversitesi Sosyal Bilimler Dergisi, 1427-1436.

Onursoy, S. (2018). Üniversite Gençliğinin Dijital Okuryazarlık Düzeyleri: Anadolu Üniversitesi Öğrencileri Üzerine Bir Araştırma. Gümüşhane Üniversitesi Iletişsim Fakültesi Elektronik Dergisi, 989-1013.

Official Journal of the European Union. (2006). Recommendation of the European Parliament and of the Council of 18 December 2006 on key competences for lifelong learning. European Union.

Pereira, I., Ramos, A., \& Marsh, J. (2016). The Digital Literacy and Multimodal Practices of Young Children: Engaging with Emergent Research. University of Minho.

Schonard, M. (2018). The underlying causes of the digital gender gap and possible solutions for enhanced digital inclusion of women and girls. Brussels: European Parliament, Policy Department for Citizen's Rights and Constitutional Affairs.

Spante, M., Hashemi, S. S., Lundin, M., \& Alger, A. (2018). Digital competence and digital literacy in higher education research: Systematic review of concept use. Cogent Education, 1-21.

Tekin, A., \& Polat, E. (2017). Öğretmen Adaylarının Sayısal Yetkinlik Düzeyleri ve Çevrimiçi Bilgi Arama Stratejilerinin Değerlendirilmesi. Trakya Üniversitesi Eğitim Fakültesi Dergisi, 635-658.

Timur, B., \& Timur, S. (2014). Öğretmen Adaylarının Sayısal Yetkinlik Düzeylerinin Belirlenmesi. Muğla Sıtkı Koçman Üniversitesi Sosyal Bilimler Enstitüsü Dergisi, 41-59.

Vieru, D. (2015). Towards a Multi-Dimensional Model of Digital Competence in Small- and Medium-Sized Enterprises. Encyclopedia of Information Science and Technology, Third Edition. 


\section{DİJITTAL OKURYAZARLIK ÖLÇEĞİ}

$\mathrm{Bu}$ ölçek lisans öğrencileri ve lisans eğitimini tamamlamış bireylerin dijital okuryazarlık düzeylerini ve alt boyutlarını belirlemeyi amaçlamaktadır. Aşağıda dijital okuryazarlığa dair çeşitli yetkinlikler yer almaktadır. Lütfen verilen yetkinlikleri dikkatle okuyarak kendi düzeyinize uygun olan seçeneği işaretleyiniz.

Akademik amaçla geliştirilen bu ölçekten toplanan veriler kesinlikle başka kişi ve kurumlarla paylaşılmayacaktır. İçtenlikle doldurduğunuz takdirde doğru verilere ulaşılmasında büyük katkılarınız olacaktır. Hiçbir maddeyi boş bırakmayınız. Göstereceğiniz ilgi ve katkılarınız için şimdiden teşekkür ederim.

\begin{tabular}{|c|c|c|c|c|c|c|}
\hline & DİJiTAL OKURYAZARLIK ÖLÇEĞİ & 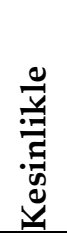 & 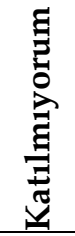 & 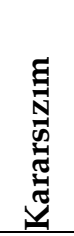 & 胥 & 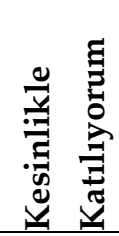 \\
\hline \multirow{7}{*}{$\begin{array}{l}\text { Etik ve } \\
\text { Sorumluluk }\end{array}$} & $\begin{array}{l}\text { Günlük hayatta olduğu gibi dijital ortamlarda da kişisel } \\
\text { veya yasal haklarımın (mahremiyet, telif, konuşma } \\
\text { özgürlüğü vb.) devam ettiğinin farkındayım. }\end{array}$ & 1 & 2 & 3 & 4 & 5 \\
\hline & $\begin{array}{l}\text { Çevrim içi ortamlarda kendimin ve başkalarının kişisel } \\
\text { verilerini (fotoğraf, adres, aile bilgileri vb.) korumak için } \\
\text { nasıl davranmam gerektiğini bilirim. }\end{array}$ & 1 & 2 & 3 & 4 & 5 \\
\hline & $\begin{array}{l}\text { Çevrim içi ortamlarda eriştiğim bilgilerin doğru olup } \\
\text { olmadığını farklı kaynaklardan sorgulayabilirim. }\end{array}$ & 1 & 2 & 3 & 4 & 5 \\
\hline & $\begin{array}{l}\text { Çevrim içi ortamlarda siber zorbalık (aşağılama, küfür, } \\
\text { nefret söylemi vb.) ve istismar gibi davranışların etik ve } \\
\text { yasal sorumluluklarının farkındayım. }\end{array}$ & 1 & 2 & 3 & 4 & 5 \\
\hline & $\begin{array}{l}\text { Bilişsel ve ahlakî gelişime uygun olan dijital oyunları ve } \\
\text { içerikleri ayırt edebilirim. }\end{array}$ & 1 & 2 & 3 & 4 & 5 \\
\hline & $\begin{array}{l}\text { Çevrim içi ortamlarda yaptığım her şeyin } \\
\text { kaydedildiğinin farkındayım. }\end{array}$ & 1 & 2 & 3 & 4 & 5 \\
\hline & $\begin{array}{l}\text { Dijital ortamlarda telif haklarının ihlalinden } \\
\text { doğabilecek etik ve yasal sorumlulukların farkındayım. }\end{array}$ & 1 & 2 & 3 & 4 & 5 \\
\hline \multirow{4}{*}{$\begin{array}{l}\text { Genel Bilgi } \\
\text { ve İşlevsel } \\
\text { Beceriler }\end{array}$} & $\begin{array}{l}\text { Lisanslı yazılım, demo yazılım, korsan yazılım, kötü } \\
\text { amaçlı yazılım ve crack kavramlarının ne olduğunu } \\
\text { bilirim. }\end{array}$ & 1 & 2 & 3 & 4 & 5 \\
\hline & $\begin{array}{l}\text { Donanım ve yazılım teknolojilerinin ne olduğunu } \\
\text { bilirim. }\end{array}$ & 1 & 2 & 3 & 4 & 5 \\
\hline & $\begin{array}{l}\text { Bilgisayarıma işletim sistemini kurabilirim/format } \\
\text { atabilirim. }\end{array}$ & 1 & 2 & 3 & 4 & 5 \\
\hline & $\begin{array}{l}\text { Bilgisayarıma ya da diğer elektronik cihazlarıma } \\
\text { yazılım veya program yükleyebilirim. }\end{array}$ & 1 & 2 & 3 & 4 & 5 \\
\hline
\end{tabular}




\section{AJIT-e Bilişim Teknolojileri Online Dergisi \\ Academic Journal of Information Tecnology}

2021 Summer/Yaz - Cilt/Vol: 12 - Sayı/Issue: 46

10.5824/ajite.2021.03.003.x

\begin{tabular}{|c|c|c|c|c|c|c|}
\hline & $\begin{array}{l}\text { Torent, İnternet, World Wide Web (WWW) ifadelerinin } \\
\text { ne anlama geldiğini bilirim. }\end{array}$ & 1 & 2 & 3 & 4 & 5 \\
\hline & $\begin{array}{l}\text { Yasaklı İnternet sitelerine erişmek için cihazların } \\
\text { proxy/dns ayarlarını değiştirebilirim. }\end{array}$ & 1 & 2 & 3 & 4 & 5 \\
\hline \multirow{6}{*}{$\begin{array}{l}\text { Günlük } \\
\text { Kullanım }\end{array}$} & $\begin{array}{l}\text { e-Devlet uygulamalarını (MHRS, UYAP, vergi\&ceza } \\
\text { sorgulama vb.) etkin kullanabilirim. }\end{array}$ & 1 & 2 & 3 & 4 & 5 \\
\hline & $\begin{array}{l}\text { Bulut bilişim teknolojilerini (Google Drive, iCloud, } \\
\text { Dropbox vb.) günlük hayatta etkin kullanabilirim. }\end{array}$ & 1 & 2 & 3 & 4 & 5 \\
\hline & $\begin{array}{l}\text { Mobil cihazlarda takvimi sadece tarihe bakmak için } \\
\text { değil; aynı zamanda anımsatıcı, not alma, etkinlik } \\
\text { oluşturma vb. işler için de kullanabilirim. }\end{array}$ & 1 & 2 & 3 & 4 & 5 \\
\hline & $\begin{array}{l}\text { Çevrim içi ortamlarda "video yüklemek/canlı yayın } \\
\text { yapmak" gibi etkinliklerde bulunabilirim }\end{array}$ & 1 & 2 & 3 & 4 & 5 \\
\hline & \begin{tabular}{|l} 
Rezervasyon, alışveriş, adres bulma vb. gündelik \\
pratiklerde dijital teknolojileri etkin kullanabilirim.
\end{tabular} & 1 & 2 & 3 & 4 & 5 \\
\hline & $\begin{array}{l}\text { Kullandığım bir web sayfasını sık kullanılanlara veya } \\
\text { yer imlerine ekleyebilirim. }\end{array}$ & 1 & 2 & 3 & 4 & 5 \\
\hline \multirow{2}{*}{$\begin{array}{l}\text { Profesyonel } \\
\text { Üretim }\end{array}$} & $\begin{array}{l}\text { Dijital teknolojilere dayalı yazılım/uygulama } \\
\text { geliştirebilirim. }\end{array}$ & 1 & 2 & 3 & 4 & 5 \\
\hline & $\begin{array}{l}\text { Programlama dillerinden (Java, C, Visual Basic, PHP, } \\
\text { vb. ) en az birini kullanabilirim. }\end{array}$ & 1 & 2 & 3 & 4 & 5 \\
\hline \multirow{4}{*}{$\begin{array}{l}\text { Gizlilik ve } \\
\text { Güvenlik }\end{array}$} & $\begin{array}{l}\text { Uygulamaların kişisel bilgilerime (konum, rehber, } \\
\text { kamera vb. ) erişimini kısıtlamayı bilirim. }\end{array}$ & 1 & 2 & 3 & 4 & 5 \\
\hline & $\begin{array}{l}\text { İstenmeyen/spam epostaları ve oltalama mesajları } \\
\text { tanıyp engelleyebilirim. }\end{array}$ & 1 & 2 & 3 & 4 & 5 \\
\hline & $\begin{array}{l}\text { Sosyal ağlardaki paylaşımlarımda ve profilimdeki } \\
\text { gizlilik/güvenlik ayarlarını değiştirebilirim. }\end{array}$ & 1 & 2 & 3 & 4 & 5 \\
\hline & Nasıl güçlü bir şifre oluşturacağımın farkındayım. & 1 & 2 & 3 & 4 & 5 \\
\hline \multirow{4}{*}{ Sosyal Boyut } & $\begin{array}{l}\text { Web tasarım sistemlerini (Weebly, Wordpress vb. ) } \\
\text { kullanarak İnternet sitesi tasarlayıp yayınlayabilirim. }\end{array}$ & 1 & 2 & 3 & 4 & 5 \\
\hline & $\begin{array}{l}\text { Kendi blog sayfamda veya farklı bloglarda yazı yazıp, } \\
\text { paylaşabilirim. }\end{array}$ & 1 & 2 & 3 & 4 & 5 \\
\hline & $\begin{array}{l}\text { Dijital teknolojiler yardımıyla çeşitli imajları (fotoğraf, } \\
\text { ses kaydı ve video vb.) değiştirip, yeni içerikler } \\
\text { üretebilirim. }\end{array}$ & 1 & 2 & 3 & 4 & 5 \\
\hline & $\begin{array}{l}\text { Alanımla ilgili en az bir tane yazılımı (Photoshop, SPSS, } \\
\text { Premiere, Office Word vb.) etkili bir şekilde } \\
\text { kullanabilirim. }\end{array}$ & 1 & 2 & 3 & 4 & 5 \\
\hline
\end{tabular}

